of the empirical world, and hence in many it tends to become pathological. The relationship between the various neurotic types and expressionists is discussed.

It is a very interesting study, both of a particular man and of an art movement; but the method of writing is discursive, and the book might with advantage be considerably condensed.

The Races of England and Wales : a Survey of Recent Research. By Prof. H. J. Fleure. Pp. ix8. (London : Benn Bros., Ltd., 1923.) 5s. net.

Prof. Fleure's modest claim to have given in this work a survey of recent research is an understatement which may give a misleading idea of its very real importance as a contribution to the ethnology of England and Wales-an idea which the brevity of the book does nothing to remove. It summarises in a fair and judicial spirit the results of the observations of anthropologists on the physical characters of the peoples of England and Wales, both in prehistoric and in recent times, to which Prof. Fleure himself has contributed in no small degree; but it does far more than this. It reviews these results in the light of certain general conclusions on the question of the development of racial type at which Prof. Fleure has arrived. The inferences which he has drawn in consequence cannot fail to have a profound influence on the future discussion of British ethnology as well as to stimulate observation in certain directions in the future in support or refutation of his views. Of these, perhaps the most important is that the intermediate type, which forms a common element in the population of Britain, and is usually taken to be a combination of Nordic and Mediterranean, represents in reality an independent "descent with modification" within this country from a palæolithic type.

Cryptography. By André Langie. Translated from the French by J. C. H. Macbeth. Pp. viii + rg2. (London, Bombay and Sydney : Constable and Co., Ltd., I922.) 9s. net.

As there is no manual of cryptography in English, this book, which is translated from the French, will be welcomed by all who wish to make a serious study of the subject, either for practical purposes or as an intellectual exercise. The author deals with his subject under three heads. Under the first he gives a brief history of the methods of conveying information secretly, beginning with the Greeks, Egyptians, and Romans; under the second he gives examples of cryptographical writings of which he himself has found the solution, for the most part, during the War; and under the third he gives lists and tables of frequency of single letters, bigrams, and other combinations in English and other languages. This section will naturally be one of the most frequently consulted in the book, as a knowledge of the relative frequency of occurrence of the different letters and combinations is essential in all decipherment. The translator adds a supplementary chapter dealing with methods of conveying information secretly, such as the use of sympathetic inks, tramps' signs, the marking of cards by cardsharpers, and the like, and describes the Playfair cipher, a substitution system extensively used for military purposes, Commander W. W. Smith, United States Navy, adding a note on its solution.
Botulism and Food Preservation (The Loch Maree Tragedy). By Dr. Gerald Leighton. Pp. xiii +237 . (London: W. Collins, Sons and Co., Ltd., r923.) Ios. net.

DR. LeightoN's report on the outbreak of botulism at Loch Maree in 1922 has been already noticed in NATURE (March 24, p. 4I5) and some account has also been given of the comprehensive researches of Prof. K. F. Meyer, of the University of California, into the distribution and biology of the responsible microbe (January 20, p. 95). In the present volume Dr. Leighton has collected into a convenient form most of the available information about the disease as it occurs in man and animals. Originally most frequently associated with sausages and especially common in Würtemberg, most of the recent cases have been identified in America and more commonly with canned vegetables than meat products. "Limberneck" in poultry appears to be botulism, and "grass sickness" of horses is either this or a closely allied condition. Prevention is a question of the adequate sterilisation of preserved foods. The second part of the book recounts the details of the tragedy of the potted duck sandwiches and concludes with an ample bibliography.

The Annual Register: a Review of Public Events at Home and Abroad for the Year I922. Edited by Dr. M. Epstein. Pp. xii $+3 \mathrm{I} 6+\mathrm{r} 99$. (London : Longmans, Green and Co., r923.) 30s. net.

A wORK of reference that has reached its hundred and sixty-fourth volume requires no commendation. This annual review of the year has an established place among indispensable works of reference. English history, which appears to include Irish history, and foreign and colonial history occupy about two-thirds of the book, in a summary which is conspicuous for its impartiality and lucidity. A chronicle of events is less well-balanced but extremely useful. The year's obituary gives biographical sketches of about 300 eminent men and women of all countries. Literature of the year is dealt with in a forty-page summary, which is a comprehensive and, to a large extent, critical survey of the year's books. Science has to be content with a twelve-page summary, which, however, ranges over so wide a field that little, if anything, of notable value is omitted. A full index enhances the value of the book.

\section{A Text-Book of Machine Construction and Drawing.} By H. E. Merritt and M. Platt. Pp. $x+r 97$. (London: G. Bell and Sons, Ltd., I922.) 7s. $6 d$. net.

TEAchers of classes dealing with machine construction and drawing are frequently put to a great deal of trouble in seeking for modern examples to put before their students. Text-books on the subject go out-ofdate, and on account of the great strides which have been made in recent years in the manufacture of engineering materials, and in their treatment in the machine shop, and consequently in design, details have shown an increasing tendency to become obsolete. The volume before us contains a large number of designs suitable for students, and all of these examples are up-to-date. The authors make use of the American system of projection, and there is sufficient practical geometry included for the purposes of the draughtsman. 